\title{
COVID-19 PANDEMIC: HOW STRESSED THE STUDENTS AND FACULTY ARE?
}

\author{
Kinza Aslam¹, Syed Hussain Raza Zaidi', Mahwish Arooj ${ }^{1}$, Ahsan Sethi \\ 'Department of Medical Education, The University of Lahore, Lahore - Pakistan \\ ${ }^{2}$ Department of Public Health, College of Health Sciences, QU Health, Qatar University, Doha - Qatar
}

\begin{abstract}
Objective: To assess the perceived stress levels amongst faculty and students of medicine, dentistry and allied health sciences during COVID-19 pandemic.

Material and Method: This multi-institutional descriptive study was conducted from April to June 2020. All the students and faculty from three institutes namely University College of Medicine, University College of Dentistry and the Institute of Allied Health Sciences were invited to participate. Data was collected using a pre-validated Perceived Stress Scale (PSS -10). descriptive and inferential statistics were calculated using SPSS v.21.

Results: 1199 responses were obtained. Students from the University College of Medicine reported higher scores on the Perceived Stress Scale $(23.02+11.85)$ than those from the University College of Dentistry $(21.87+10.86)$ and the Institute of Allied Health Sciences $(21.95+11.32)$. The students and the faculty experienced stress 'sometimes to fairly often' during this pandemic. Females experienced more stress than males and there was no significant difference among students and faculty of various age groups.

Conclusion: During the COVID-19 pandemic, the students and the faculty from medicine, dentistry and allied health sciences institutes were moderately stressed. The medical students were more affected than the allied health and dental students. A higher stress level was reported among dental faculty as compared to the other two institutes. Institutions should hence promote resilience and mental well-being and provide for more flexible work schedules.
\end{abstract}

Keywords: Allied Health Sciences, COVID-19, Dentistry, Medicine, Mental Health, Pandemic, Stress

This article may be cited as: Aslam K, Zaidi SHR, Arooj M, Sethi A. COVID-19 Pandemic: How stressed the students and faculty are?. J Med Sci 2021 July;29(3):83-86

\section{INTRODUCTION}

Coronavirus disease (COVID-19), an infectious disease caused by SARS-CoV-2 was first detected in Wuhan, China in late 2019. Within thirty days, the disease that presented as pneumonia of unknown cause was declared to be a public health emergency of international concern ${ }^{1}$. Within two months, over thirty thousand people had lost their lives to the pandemic. By August 4, 2020, over 18 million confirmed cases of COVID-19 had been reported, resulting in more than 691,013 deaths in 216 countries ${ }^{1}$.

To slow down the progression of the disease and flatten the curve, many aggressive measures were taken which included travel restrictions, avoidance of social interactions, closure of academic institutions and other

\section{Correspondence}

Dr. Kinza Aslam

Assistant Professor

Department of Medical Education, The University of

Lahore, Lahore - Pakistan

Email: kinza.aslam@ucm.uol.edu.pk

Cell: +92-323-4192922

Date received: $\quad 02-05-2021$

Date revised: 21-06-2021

Date accepted: $\quad$ 07-07-2021 non-essential services such as private clinics, hospital OPDs and elective procedures. By April 2020, 192 countries had announced the closure of educational institutions, impacting $91.4 \%$ of the total enrolled learners ${ }^{2}$. This had a significant impact on the mental, physical and social well-being of learners ${ }^{3}$.

To minimise the academic loss, Higher Education Commission (HEC), Pakistan issued guidelines on delivery of online courses ${ }^{4}$. As a result, most of the universities made a rapid transition from face to face, towards online teaching. Academicians reported this transition to be stressful as 'work from home' affected their worklife balance and teaching students remotely meant they had to find new ways to engage students academically ${ }^{3}$. Most of them were not familiar with online teaching tools required to ensure a meaningful learning experience for their students ${ }^{5}$. Likewise, this transition in the learning environment was difficult for students, who reported a limited attention span while taking online lectures. They also reported that while online learning offers some flexibility in terms of accessing learning material, it also limits the development of proficiency in certain domains of learning such as psychomotor skills ${ }^{6}$. While the younger generation maybe more comfortable with using technology as 
compared to the older generation, online teaching and learning poses its own challenges, especially in countries such as Pakistan where resources are constrained.

The potential ramifications of all the emergency measures taken during the COVID-19 pandemic cannot be ignored. These may have resulted in increased anxiety and stress among students and the faculty. To develop timely interventions for improving the mental, physical and social wellbeing, we need to establish this impact on the students and the faculty objectively. Hence, this study explores the perceived stress levels amongst faculty and students of medicine, dentistry and allied health sciences during the COVID-19 pandemic.

\section{MATERIALS AND METHODS}

This multi-institutional descriptive study was conducted from April to June 2020. Ethical approval was obtained from the Ethical Review Board, The University of Lahore (Ref\# ERC/08/20/14 Dated 17 ${ }^{\text {th }}$ March 2020). Using convenience sampling, all the students $(n=2850)$ and faculty $(n=305)$ from three institutes namely University College of Medicine, University College of Dentistry and Institute of Allied Health Sciences were invited to participate using their Learning Management System (Moodle).

Data were collected using a pre-validated Perceived Stress Scale (PSS -10). The PSS-10 assesses the perceptions, feelings and thoughts of stress on 10 items using a five-point Likert scale $(0=$ never, $1=$ almost never, 2 =sometimes, $3=$ fairly often, $4=$ very often). It measures the degree to which life in the past month has been experienced as unpredictable, uncontrollable and overwhelming 7. It has high reliability with Cronbach's alpha=0.79-0.82. Standard demographic questions were added, and the questionnaire was piloted with 10 students to ensure online accessibility and comprehensiveness.

Descriptive and inferential statistics were calculated using SPSS v.21. The total score was obtained by summing up the individual scores for all ten items. Four items $(4,5,7, \& 8)$ were positively worded hence their scores were reversed. A mean score of 2-4 for an item indicates sometimes to very often having such feelings/ thoughts during the last month. Frequencies and percentage were calculated for the demographic data. As the data was not normally distributed, therefore, Kruskal Wallis and Mann-Whitney $U$ tests were applied to investigate the mean differences between institutions, students and faculty, gender and age groups.

\section{RESULTS}

A total of 1199 responses were obtained from the University College of Medicine $(n=355)$, University College of Dentistry $(n=195)$ and Institute of Allied Health Sciences $(n=649)$. Of these 159 respondents were faculty members, while 1040 were students. The age of the par- ticipants was between 18 and 60 years however, most of the respondents were female and from age range of 18-37 years. (Table I).

Table 2 shows the stress levels among students and faculty based on their institution and gender. Students from University College of Medicine reported higher score on the perceived stress scale $(23.02 \pm 11.85)$ than those from University College of Dentistry $(21.87 \pm 10.86)$ and Institute of Allied Health Sciences $(21.95 \pm 11.32)$. A higher stress level was reported among faculty of University College of Dentistry $(18.71 \pm 9.99)$. The differences among cumulative scores of the institutes was not significant. However, the medical students did report significantly higher scores on various items of the PSS-10 scale. The mean scores of students and faculty on all items suggests that they had experienced stress 'sometimes to fairly often' during this pandemic. Their scores on all items and subsequently, the stress level was significantly higher than the faculty. Females experienced more stress than males and these differences were significant for all the items among faculty. There were no significant differences among students and faculty of various age groups indicating a similar impact of the pandemic on all age groups.

\section{DISCUSSION}

The students and the faculty from medicine, dentistry and allied health sciences institutes had moderate stress levels during COVID-19 pandemic. The finding that females experienced significantly more stress than males during the on-going pandemic is in line with the previously conducted studies across European countries ${ }^{8,9}$. A Chinese study conducted during the peak of this pandemic also reported that females were more vulnerable in developing anxiety and depression as a result of being exposed to constant stress. It has been reported that all health professionals, irrespective of gender, are stressed and anxious as they are struggling to strike a balance between teaching and providing healthcare, while ensuring their own safety as well as of their families ${ }^{3}$. There is a need for equity-based policies to control stress and anxiety among females.

The stress levels were higher amongst students in comparison to the faculty. The students reported being unable to control the important things in their lives. This is consistent with findings in literature, as students have reported to find the situation 'unnerving' ${ }^{10}$. The uncertainty of the situation and the question as to when life will go back to normal may have also led to increased levels of anxiety amongst students. Such stress has a negative impact on the mental well-being and in turn the learning capabilities of students ${ }^{11}$. The stress levels may have been aggravated by the transition from face to face towards online teaching and learning. With online teaching and learning, students have reported limited attention spans and increased cognitive load 6 . Many have also identified e-learning to be resource intensive and not all students have access to good quality gadgets and high speed In- 
Covid-19 Pandemic: How Stressed The Students And Faculty Are?

Table 1: Age-wise distribution of ED patients in both Groups (200)

\begin{tabular}{|c|c|c|c|c|c|c|c|}
\hline & \multirow[t]{2}{*}{ Type } & \multirow{2}{*}{$\begin{array}{c}\begin{array}{c}\text { University } \\
\text { College of } \\
\text { Medicine }\end{array} \\
\text { Mean+ SD }\end{array}$} & \multirow{2}{*}{$\begin{array}{c}\begin{array}{c}\text { University } \\
\text { College of } \\
\text { Dentistry }\end{array} \\
\text { Mean+ SD }\end{array}$} & \multirow{2}{*}{$\begin{array}{l}\text { Allied Health } \\
\text { Sciences } \\
\text { Mean+ SD }\end{array}$} & \multicolumn{3}{|c|}{$P$ value } \\
\hline & & & & & $\begin{array}{c}\text { UCM vs UCD } \\
\text { vs AHS }\end{array}$ & $\begin{array}{l}\text { Faculty } \\
\text { vs Stu- } \\
\text { dents }\end{array}$ & $\begin{array}{l}\text { Male } \\
\text { vs Fe- } \\
\text { male }\end{array}$ \\
\hline \multirow{2}{*}{$\begin{array}{c}\text { 1. In the last month, how often } \\
\text { have you been upset because } \\
\text { of something that happened } \\
\text { unexpectedly? }\end{array}$} & Students & $2.46+1.12$ & $2.48+1.15$ & $2.55+1.10$ & 0.537 & \multirow[t]{2}{*}{$0.024^{\star}$} & $0.007^{*}$ \\
\hline & Faculty & $2.29+0.99$ & $2.47+1.00$ & $2.35+1.00$ & 0.66 & & $0.002^{*}$ \\
\hline \multirow{2}{*}{$\begin{array}{l}\text { 2. In the last month, how often } \\
\text { have you felt that you were } \\
\text { unable to control the important } \\
\text { things in your life? }\end{array}$} & Students & $2.39+1.14$ & $2.36+1.09$ & $2.36+1.21$ & 0.86 & \multirow[t]{2}{*}{$0.0002^{*}$} & $0.007^{*}$ \\
\hline & Faculty & $1.84+1.17$ & $2.37+1.15$ & $1.85+1.16$ & 0.12 & & $0.00^{*}$ \\
\hline \multirow{2}{*}{$\begin{array}{l}\text { 3. In the last month, how often } \\
\text { have you felt nervous and } \\
\text { stressed? }\end{array}$} & Students & $1.11+2.64$ & $1.19+2.44$ & $1.17+2.59$ & 0.256 & \multirow[t]{2}{*}{$0.000^{*}$} & $0.005^{*}$ \\
\hline & Faculty & $0.88+2.33$ & $1.18+2.33$ & $0.98+2.00$ & 0.15 & & $0.0001^{*}$ \\
\hline \multirow{2}{*}{$\begin{array}{l}\text { 4. In the last month, how often } \\
\text { have you felt unconfident about } \\
\text { your ability to handle your per- } \\
\text { sonal problems? }(+)\end{array}$} & Students & $1.07+1.62$ & $0.99+1.36$ & $1.02+1.54$ & $0.02^{*}$ & \multirow[t]{2}{*}{$0.0004^{*}$} & 0.120 \\
\hline & Faculty & $0.72+1.00$ & $0.92+1.20$ & $0.98+1.10$ & 0.61 & & $0.00^{*}$ \\
\hline \multirow{2}{*}{$\begin{array}{l}\text { 5. In the last month, how often } \\
\text { have you felt that things were } \\
\text { not going your way? (+) }\end{array}$} & Students & $1.10+2.23$ & $1.13+2.18$ & $1.12+2.13$ & 0.29 & \multirow[t]{2}{*}{$0.0005^{*}$} & 0.53 \\
\hline & Faculty & $0.92+1.58$ & $0.99+1.67$ & $0.91+1.68$ & 0.87 & & $0.006^{*}$ \\
\hline \multirow{2}{*}{$\begin{array}{c}\text { 6. In the last month, how often } \\
\text { have you found that you could } \\
\text { not cope with all the things that } \\
\text { you had to do? }\end{array}$} & Students & $1.69+2.40$ & $1.05+2.09$ & $1.07+2.11$ & $0.001^{*}$ & \multirow[t]{2}{*}{$0.002^{*}$} & 0.051 \\
\hline & Faculty & $1.00+1.91$ & $1.08+2.17$ & $0.83+1.78$ & 0.28 & & $0.0003^{*}$ \\
\hline \multirow{2}{*}{$\begin{array}{l}\text { 7. In the last month, how often } \\
\text { have you been unable to con- } \\
\text { trol irritations in your life? (+) }\end{array}$} & Students & $1.06+2.12$ & $1.06+1.85$ & $1.10+1.81$ & $0.0003^{*}$ & \multirow[t]{2}{*}{$0.00 *$} & 0.166 \\
\hline & Faculty & $0.82+1.29$ & $0.99+1.33$ & $1.19+1.60$ & 0.49 & & $0.004^{*}$ \\
\hline \multirow{2}{*}{$\begin{array}{l}\text { 8. In the last month, how often } \\
\text { have you felt that you were not } \\
\text { on top of things? (+) }\end{array}$} & Students & $1.14+2.39$ & $1.01+2.36$ & $1.13+2.13$ & $0.006^{*}$ & \multirow[t]{2}{*}{$0.002^{*}$} & 0.379 \\
\hline & Faculty & $1.05+1.98$ & $0.93+1.87$ & $0.90+2.05$ & 0.79 & & $0.026^{*}$ \\
\hline \multirow{2}{*}{$\begin{array}{l}\text { 9. In the last month, how often } \\
\text { have you been angered be- } \\
\text { cause of things that happened } \\
\text { that were outside of your } \\
\text { control? }\end{array}$} & Students & $1.16+2.44$ & $1.04+2.42$ & $1.18+2.49$ & 0.58 & \multirow[t]{2}{*}{$0.0001^{*}$} & $0.042^{*}$ \\
\hline & Faculty & $1.09+2.01$ & $0.86+1.87$ & $1.08+2.00$ & 0.82 & & $0.00 *$ \\
\hline \multirow{2}{*}{$\begin{array}{l}\text { 10. In the last month, how often } \\
\text { have you felt difficulties were } \\
\text { piling up so high that you could } \\
\text { not overcome them? }\end{array}$} & Students & $1.26+2.33$ & $1.15+2.33$ & $1.21+2.24$ & 0.433 & \multirow[t]{2}{*}{$0.0007^{*}$} & 0.090 \\
\hline & Faculty & $1.22+1.85$ & $0.89+1.43$ & $1.10+1.63$ & 0.22 & & 0.0001 * \\
\hline \multirow[t]{2}{*}{ Total } & Students & $11.85+23.02$ & $10.86+21.87$ & $3111+21.95$ & 0.29 & \multirow[t]{2}{*}{$0.002^{*}$} & 0.13 \\
\hline & Faculty & $9.86+18.08$ & $9.99+18.71$ & $10.13+18.04$ & 0.50 & & 0.003 \\
\hline
\end{tabular}

* The differences are significant $(p<0.05)$. + Four statements were originally positive, therefore reversed.

ternet ${ }^{6}$. This is alarming as perceived stress is shown to have a strong positive correlation with fatigue, depression and procrastination ${ }^{9}$.

The results of our study highlighted that medical students experienced higher stress than the dental and allied health students. This is consistent with findings from literature, which states the mental health of medical students to be poorer in comparison with other students ${ }^{12}$. A global study that was conducted to assess the mental health of medical students also concluded that medical students show high levels of mental stress and depression and are hence most likely to resort to substance abuse as a coping strategy ${ }^{13}$. Academic stress is a major factor that contributes towards the increased stress levels of medical students. This stress coupled with the on-going pandemic, lack of on-campus activities and peer interaction may have further aggravated the situation ${ }^{14}$.

As stress levels have been determined and the most stressed subpopulations has been identified, the findings of this study can assist administrators in chalking a plan of action for looking after the mental health of students and faculty. In light of the insight gained by this study, the institutions should assess mental health and provide for necessary services to the students. The first step can be holding open discussions on mental health to remove the stigma around it. Allowing flexible study 
or work schedules, so neither the students nor faculty feels overwhelmed by the workload. Additionally, online counselling sessions, workshops on coping and stress management such as through mindfulness-based stress reduction exercises may also be useful. Taking timely corrective measures is imperative to maintain the psychological wellbeing of both students and faculty members. It is important to highlight that stress and mental health are still stigmatized in the country and further research needs to be undertaken to identify the most suitable modality for ensuring emotional wellbeing of students and the faculty.

We could not find any studies that used PSS-10 scale to measure stress among students and the faculty during the pandemic, therefore comparison of all aspects of the results was not possible. All the medical, dental and allied health science institutions were affiliated by a single university from Lahore, Pakistan. Therefore, similar studies are needed from institutions in other provinces of Pakistan.

\section{CONCLUSION}

During COVID-19 pandemic, the students and the faculty from the medicine, dentistry and allied health sciences institutes were moderately stressed. The pandemic had a significant impact on all the age groups. The medical students were more affected than the allied health students and the faculty. Likewise, the females were in more distress than males. Institutions should hence promote resilience by offering support services to manage mental health conditions. Future studies should explore the lived experiences of the students during pandemic qualitatively.

\section{ACKNOWLEDGEMENT}

The authors would like to thank Ms. Tehseen for her input in the statistical analysis and the participants for their time and contribution.

\section{REFERENCES}

1. WHO. World Health Organisation Corona Virus Disease (COVID - 19) outbreak situation [Internet]. 2020 [cited 2020 Apr 15].

2. UNESCO. COVID 19 - Educational Disruption \& Response [Internet]. 2020 [cited 2020 Apr 13].

3. Sethi BA, Sethi A, Ali S, Aamir HS. Impact of Coronavirus disease (COVID-19) pandemic on health professionals. Pak J Med Sci. 2020 May;36(COVID19-S4):S6.

4. Higher Education Commission, HEC COVID-19 Policy Papers Policy Guidance Note 5: Online Readiness [Internet]. [cited 2020 Apr 22].

5. Gewin V. Five tips for moving teaching online as COVID-19 takes hold. Nature [Internet]. 2020 Apr 24 [cited 2020 Apr 15];580(7802):295-6.

6. Mukhtar K, Javed K, Arooj M, Sethi A. Advantages, Limitations and Recommendations for online learning during COVID-19 pandemic era. Pak J Med Sci. 2020 May;36(-
COVID19-S4):S27.

7. Cohen S, Kamarck T, Mermelstein R. A global measure of perceived stress. J health and social behavior. 1983 Dec 1:385-96.

8. Lesage FX, Berjot S, Deschamps F. Psychometric properties of the French versions of the Perceived Stress Scale. Inter J occup med and environ health. 2012 Jun;25(2):178-84.

9. Klein EM, Brähler E, Dreier M, Reinecke L, Müller KW, Schmutzer G, et al. The German version of the Perceived Stress Scale - psychometric characteristics in a representative German community sample. BMC Psychiatry [Internet]. BioMed Central; 2016 Dec 23;16(1):159.

10. Kafka AC. Shock, fear, and fatalism: as coronavirus prompts colleges to close, students grapple with uncertainty. The Chronicle of Higher Education. 2020 Mar $12 ; 12$.

11. Al-Rabiaah A, Temsah MH, Al-Eyadhy AA, Hasan GM, Al-Zamil F, Al-Subaie S, Alsohime F, Jamal A, Alhaboob A, Al-Saadi B, Somily AM. Middle East Respiratory Syndrome-Corona Virus (MERS-CoV) associated stress among medical students at a university teaching hospital in Saudi Arabia. J inf and public health. 2020 May 1;13(5):687-91.

12. O'Byrne L, Gavin B, McNicholas F. Medical students and COVID-19: the need for pandemic preparedness. J Med Ethics. 2020 Sep 1;46(9):623-6.

13. Farrell SM, Moir F, Molodynski A, Bhugra D. Psychological wellbeing, burnout and substance use amongst medical students in New Zealand. Int Rev Psychiatry. 2019 Nov 17;31(7-8):630-6.

14. Chandratre S. Medical students and COVID-19: challenges and supportive strategies. J med education and curricular development. 2020 Jun;7:2382120520935059.
CONFLICT OF INTEREST: Authors declare no conflict of interest

\section{GRANT SUPPORT AND FINANCIAL DISCLOSURE: NIL}

\section{AUTHOR'S CONTRIBUTION}

Following authors have made substantial contributions to the manuscript as under

Aslam K: $\quad$ Concept, Design and Proof reading

Zaidi SHR: Acquisition and critical review

Arooj M: $\quad$ Analysis and interpretation of data

Sethi A: Concept, Design, Final approval

Authors agree to be accountable for all aspects of the work in ensuring that questions related to the accuracy or integrity of any part of the work are appropriately investigated and resolved. 